\title{
Stratigraphy, sedimentology, and archaeology of Middle Pleistocene localities near Ceprano, Campogrande area, Italy
}

\author{
Italo Biddittu ${ }^{\mathrm{a}}$, Marie-Hélène Moncel ${ }^{\mathrm{b} *}$, Salvatore Millic,d*, Luca Bellucci ${ }^{\mathrm{a}, \mathrm{e}}$, Massimo Ruffo ${ }^{\mathrm{a}}$, Barbara Saracino $^{\mathrm{a}}$, \\ Giorgio Manzi ${ }^{\mathrm{a}, \mathrm{e}, \mathrm{f} *}$

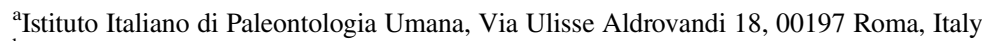 \\ ${ }^{\mathrm{b}}$ Department of Human and Environment, UMR 7194 CNRS, National Museum of Natural History, Institut de Paléontologie Humaine, Rue René Panhard, \\ 75013 Paris, France \\ ${ }^{\mathrm{c}}$ Dipartimento di Scienze della Terra, Sapienza Università di Roma, Piazzale Aldo Moro 5, 00185 Roma, Italy \\ ${ }^{\mathrm{d}}$ CNR-IGAG, Istituto di Geologia Ambientale e Geoingegneria, Area della Ricerca di Roma 1, 00015 Montelibretti (Roma), Italy \\ ${ }^{e}$ Polo museale Sapienza, Sapienza Università di Roma, Piazzale Aldo Moro 5, 00185 Roma, Italy \\ ${ }^{\mathrm{f}}$ Dipartimento di Biologia Ambientale, Sapienza Università di Roma, Piazzale Aldo Moro 5, 00185 Roma, Italy \\ *Corresponding authors E-mail address: marie-helene.moncel@mnhn.fr (M.-H. Moncel), salvatore.milli@uniroma1.it (S. Milli), giorgio.manzi@uniroma1.it \\ (G. Manzi).
}

(ReCEIVED May 29, 2018; AcCePTed July 23, 2019)

\begin{abstract}
The Ceprano human calvarium, dated around 400,000 yr, is a well-known fossil specimen. It represents significant evidence of hominin presence in the Italian peninsula during the Middle Pleistocene and may be considered representative of an archaic variant of the widespread and polymorphic species Homo heidelbergensis. Since its discovery (March 1994), systematic surveys in the Campogrande area near Ceprano, central Italy, identified 12 localities (CG1-12) with archaeological and/or paleontological assemblages. On this basis, fieldwork was carried out at Campogrande between 2001 and 2006, including drilled cores and excavations, allowing a detailed description of the stratigraphic and paleoenvironmental context associated with the human fossil specimen and the archaeological materials. In the present paper we focus on the stratigraphy and sedimentological features of the uppermost deposits, coupled with a detailed appraisal of the available lithic assemblages that mostly belongs to overlying sediments (CG9 and CG10 localities). We conclude that the Ceprano hominin died in a floodplain environment with a low topographic gradient, where a fluvial meandering channel occurred. The archaeological materials describe a network of sites that document common behavioural features of human groups of the mid-to-late Middle Pleistocene, representing evidence of the regionalization observed across Europe after Marine Oxygen Isotope Stage 12.
\end{abstract}

Keywords: Acheulean; Paleoenvironment; Middle Pleistocene; Homo heidelbergensis; Ceprano; Italy

\section{INTRODUCTION}

The mode and timing of the earliest hominin dispersals in Europe have been one of the most debated topics during the last decades in paleoanthropology (for a review, see Manzi [2016]). Nonetheless, a consensus has been reached about the presence of human populations scattered in southern regions of the continent since the Early Pleistocene, including even rare occupations of more northern latitudes (Carbonell et al., 2008; Arzarello et al., 2009; Despriée et al., 2018). It is probable that these earliest colonization stages were sporadic (e.g., Agustí et al., 2009), influenced by environmental

Cite this article: Biddittu, I., Moncel, M.-H., Milli, S., Bellucci, L., Ruffo, M., Saracino, B., Manzi, G. 2020. Stratigraphy, sedimentology, and archaeology of Middle Pleistocene localities near Ceprano, Campogrande area, Italy. Quaternary Research 93, 155-171. https://doi.org/10.1017/ qua.2019.52 and climatic conditions that were particularly important during the 1.4-0.4 Ma interval.

The time span bracketed between the late Early and the early Middle Pleistocene was characterized by a considerable change in the Earth's climate and has been defined as the Mid-Pleistocene Transition or Revolution (Maasch, 1988; Saltzman and Maasch, 1988; Maslin and Ridgwell, 2005; O’Regan et al., 2005), now also referred to as the Early-Middle Pleistocene Transition (EMPT; Ruddiman et al., 1986; Poirier and Billups, 2014; Head and Gibbard, 2015). Particularly, a significant ecological reorganization occurred during Marine Oxygen Isotope Stage (MIS) 16, around $700 \mathrm{ka}$ (e.g., Manzi et al., 2011). The recurring Homo dispersals may be regarded, therefore, as a component of the faunal renewal that arose during the late Early Pleistocene and at the onset of the Middle Pleistocene, when large mammals of ultimate African and Asian origin spread in Western Europe (e.g., Moncel et al., 2013, 2015; Palombo, 2014). 


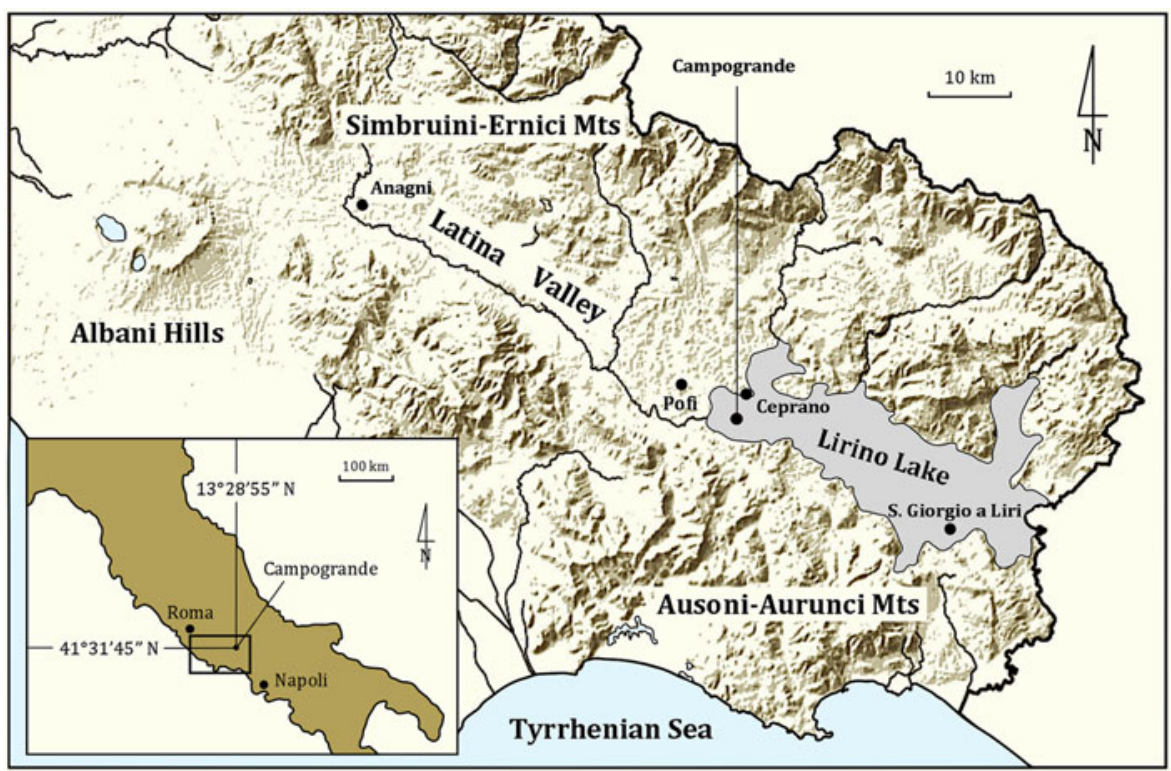

Figure 1. (color online) Location of the Campogrande area near Ceprano in the Italian peninsula and, particularly, in southern Latium, approximately midway between Rome and Naples, along the Latina Valley (Sacco river). The gray area corresponds to the inferred maximum extension of the Lirino Lake during the Middle Pleistocene.

Fluctuations in global climate and the resulting ecological changes were probably one of the main constraints also for the subsequent hominin evolution in Europe, involving the relevant Paleolithic assemblages (McNabb, 2005; Moncel et al., 2015). Nevertheless, the exact relationship between the possible dispersal in Eurasia of hominins referred to Homo heidelbergensis (Rightmire, 2008; Mounier et al., 2009, 2011; Stringer 2012; Manzi, 2016) and the onset of bifacial or "Acheulean" technology remains questioned (Moncel et al., 2013).

The transition between MIS 12 and MIS 11 (the MidBrunhes event, according to some authors; Masson-Delmotte et al., 2010; Lang and Wolff, 2011; McClymont et al., 2013) represented another substantial change in climate dynamics that coincided with the end of the EMPT. Starting from this period, the archaeological record shows increased occupation, new subsistence behaviours, technical innovations (i.e., core technologies and increase of light-duty tools), and regionalization, coupled with increased social interactions (Moncel et al., 2015, 2016; Peretto et al., 2016).

A fossil specimen of special interest for this scenario is the human calvarium found in 1994 by one of us (I. Biddittu) in the area known as Campogrande, near the town of Ceprano, central Italy (Fig. 1). The site is close to the area of Colle Avarone, where archaeological and paleontological research started in the early 1970s, with the finding of a rich Acheulean assemblage (Biddittu, 1974). From a morphological point of view (Manzi et al., 2001; Mounier et al., 2011; Manzi, 2012, 2016; Di Vincenzo et al., 2017), the Ceprano calvarium may be considered as an archaic variant of the species Homo heidelbergensis, which evolved in both Africa and Eurasia during the Middle Pleistocene (Rightmire, 1998, 2008; Hublin, 2009; Stringer, 2012). It represents a reliable proxy for the original morphology of this taxon, penecontemporaneous with more derived phenotypes that were already diversifying in Africa and Eurasia.

Since its discovery, surface surveys in the area led to the mapping of twelve localities with archaeological and/or paleontological assemblages (Fig. 2), named progressively from Campogrande (CG) 1 to 12 , each sometimes including more than one archaeological unit, as reported in Table 1. Subsequently, fieldwork was carried out between 2001 and 2006 in the area between CG1 and CG9 where the human calvarium was unearthed, aimed at collecting sedimentological data.

In this paper, combining new data with a reappraisal of previous studies in the area (Muttoni et al., 2009; Manzi et al., 2010; Nomade et al., 2011; Margari et al., 2018; Pereira et al., 2018), we provide a comprehensive stratigraphy and sedimentology of the uppermost fluvio-palustrine deposits of Campogrande, including those where the human calvarium was discovered. In addition, we describe for the first time the archaeological lithic material found in the overlying fluvial deposits of the localities labelled CG9 and CG10, furnishing further constrains to ascribe the human presence at Campogrande to a period spanning around MIS 11 .

\section{GEOLOGICAL AND PALEOENVIRONMENTAL SETTING}

The Campogrande area (Fig. 1) is about $3 \mathrm{~km}$ southeast of the town of Ceprano (Latium, central Italy). It is in the Latina Valley, a sector of the Apennines that constitutes a graben that was formed in the Middle-Late Pliocene. During the Early and Middle Pleistocene this graben hosted a lacustrine basin (Devoto, 1965; Carrara et al., 1995; Galadini and Messina, 2004; Centamore et al., 2007), which extended for about $35 \mathrm{~km}$ in a northwest-southeast direction: the Lirino Lake. 


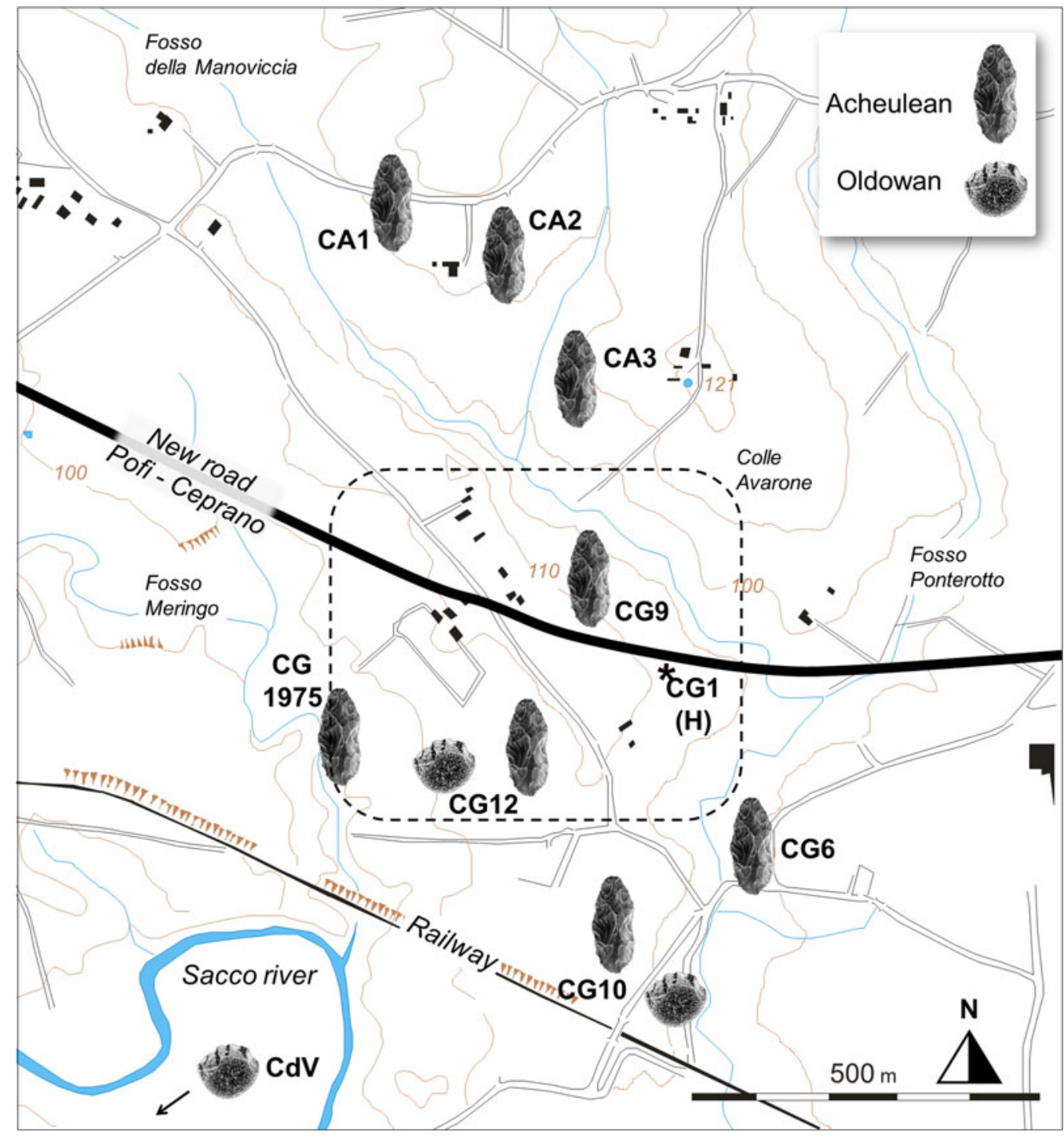

Figure 2. (color online) Topographic map of the main archaeological localities referred to the Colle Avarone (CA), Campogrande (CG), and Castro dei Volsci (CdV) areas; the symbols referred to as "Acheulean" and "Oldowan" correspond to assemblages with or without bifaces, respectively. The discovery site of the human fossil calvarium is labelled CG1 $(\mathrm{H})$. The squared dashed line corresponds to the map of Figure $3 \mathrm{a}$.

Campogrande occupies the northern sector of this basin (Fig. 1), where a primarily terrigenous sedimentation associated with volcaniclastic deposits derived from the Albani Hills volcanic complex and probably also from the Monts Ernici volcanoes (Civetta et al., 1979, 1981) occurred. The Lirino Lake succession has been recently subdivided into two main stratigraphic units bounded by erosional surfaces: LR1 below and LR2 above (Centamore and Dramis, 2010; Manzi et al., 2010).

The LR1 unit has a thickness spanning between 60 and $130 \mathrm{~m}$ and is mainly formed by lacustrine deposits. The basal portion of this unit is constituted of a lime mud with interbedded tephra layers and occupies the depocentre of the lake. The sedimentological character of the carbonate mud indicate deposition caused by microbiological activity in a sector far from the shoreline, as indicated by a pelagic fauna that is mainly represented by cold temperature molluscs, ostracods and diatoms (Devoto, 1965). The middle and upper portions of LR1 are characterized by lime sands and muds with rare volcanic material, replaced towards the lake margin by silty-mud and sands, showing intercalations of thin carbonate levels formed by Chara and scanty cemented gravel lenses with discontinuous volcanic layers. The proximity of the lake margins is confirmed by the inclined depositional profile and by the occurrence of small slumps with abundant shallow water fauna, such as gastropods and ostracods (Devoto, 1965). The tephra layers in the basal portion of LR1 have been dated to 583-570 $\pm 11 \mathrm{ka}$ and are related to the activity of the Roccamonfina volcano (Chiesa et al., 1995; Narcisi, 1995).

The LR2 unit was deposited during the maturity and the filling phase of the Lirino Lake and shows a facies variability connected to the coexistence of fluvial and lacustrine-swamp environments in which volcaniclastic layers were frequently 
Table 1. GPS coordinates and elevation above sea level ( $\mathrm{m}$ asl) of the selected localities/sites or archaeological units at Campogrande that are mentioned in the text.

\begin{tabular}{lllc}
\hline \hline & & & Elevation \\
Locality/site/unit & Latitude (N) & Longitude (E) & (m asl) \\
\hline C1 (drilled core) & $41^{\circ} 31^{\prime} 46^{\prime \prime}$ & $13^{\circ} 28^{\prime} 58^{\prime \prime}$ & 109 \\
C2 (drilled core) & $41^{\circ} 31^{\prime} 49^{\prime \prime}$ & $13^{\circ} 28^{\prime} 53^{\prime \prime}$ & 108 \\
CG.1 (or H) & $41^{\circ} 31^{\prime} 47.1^{\prime \prime}$ & $13^{\circ} 28^{\prime} 58.9^{\prime \prime}$ & 108 \\
CG.9A (or “superiore"), & $41^{\circ} 31^{\prime} 48.6^{\prime \prime}$ & $13^{\circ} 28^{\prime} 54.1^{\prime \prime}$ & 108 \\
$\quad$ including B and W & & & \\
CG.9B (or "intermedio") & $41^{\circ} 31^{\prime} 49.9^{\prime \prime}$ & $13^{\circ} 28^{\prime} 54.0^{\prime \prime}$ & 107 \\
CG.10A (or "superiore") & $41^{\circ} 31^{\prime} 32.2^{\prime \prime}$ & $13^{\circ} 28^{\prime} 54.5^{\prime \prime}$ & 110 \\
CG.10B (or & $41^{\circ} 31^{\prime} 31.1^{\prime \prime}$ & $13^{\circ} 28^{\prime} 53.3^{\prime \prime}$ & 107 \\
$\quad$ "intermedio") & & & \\
CG.10C (or "inferiore") & $41^{\circ} 31^{\prime} 29.7^{\prime \prime}$ & $13^{\circ} 28^{\prime} 57.1^{\prime \prime}$ & 103 \\
P (excavation) & $41^{\circ} 31^{\prime} 51.0^{\prime \prime}$ & $13^{\circ} 28^{\prime} 55.9^{\prime \prime}$ & 105 \\
T (trench) & $41^{\circ} 31^{\prime} 50^{\prime \prime}$ & $13^{\circ} 28^{\prime} 55^{\prime \prime}$ & 106 \\
\hline \hline
\end{tabular}

deposited (Devoto, 1965; Centamore and Dramis, 2010). Along the northern margin of the basin, LR2 is characterized by carbonate sand and mud with travertine deposits; on the southern margin, sands and fluvial mud with intercalations of volcaniclastic layers also occur. The malacofauna consists of several terricolous taxa living in shallow waters rich in limnetic plants, indicating a temperate climate (Devoto, 1965). The ostracoda assemblage is quite different from that of LR1, especially for the occurrence of crenophilous species, adapted to oligo- and mesohaline environments. This fossil assemblage indicates spring pools characterized by high concentration of $\mathrm{Ca}$ and $\mathrm{Mg}$, as also testified by travertine intercalation in the carbonate mud that also suggest the proximity of the lake shore (Devoto, 1965). The tephra layers on the upper part of LR2 are most probably derived from the Roccamonfina volcano, record the final infilling of the Lirino Lake and have been dated to $359 \pm 7$ and $354 \pm 7 \mathrm{ka}$ (Narcisi, 1995).

Starting from this period, the succeeding Middle-Upper Pleistocene and Holocene deposits are represented by terraced gravels and sandy-gravel alluvial sediments, with intercalated volcanoclastic layers, often deformed and tilted by northwest-southeast- and northeast-southwest-oriented faults that were related to the Apennine postorogenetic extensional tectonics. The latter activities have produced substantial morphostructural changes in the examined area, including the tectonically tilted deposit recorded in our trench $\mathrm{T}$ (Fig. 3, 5), the variations in the drainage pattern, the erosion of the oldest deposits, the fragmentation of the Latin paleovalley, and the tectonic depression that hosted the Lirino Lake (Centamore and Dramis, 2007).

\section{MATERIAL AND METHODS}

With the aim of refining the paleoenvironmental context of the area where the Ceprano calvarium was unearthed, the trenches and other excavations in the locality labelled CG9
(B, P, T, and $\mathrm{W}$ in Fig. 3a and b; see also Table 1) are described here according to classical sedimentological methods, integrated with data coming from two drilled cores (C1 and $\mathrm{C} 2$ in Fig. $3 \mathrm{a}$ and b; see also Table 1). Grain size and other textural attributes are reported, including sedimentary structure and color. Other features, such as the presence of shelly debris, clasts of clay, organic matter, wood fragments and roots, are also taken into consideration for the paleoenvironmental interpretation.

In order to understand the compositional characters of these deposits, nine samples were collected from trenches in the $\mathrm{P}$ and $\mathrm{T}$ sites for analysis of clay mineralogy (see Supplementary Material for the X-ray diffractometry diagrams of the samples). In the section P (Fig. 4), three samples of clays were taken: two (samples 1 and 2) from the clays at the bottom of the section (unit A), where the skull of Palaeoloxodon antiquus was found, while the third sample (sample 3) was taken in the clays at the top of the section (unit G). It is relevant that these last clays belong to the same stratigraphic interval where the human calvarium was discovered, as evidenced by the correlation between the $\mathrm{C} 1$ and $\mathrm{C} 2$ cores (Muttoni et al., 2009; Manzi et al., 2010). In the trench T (Fig. 5), six samples were taken in the units 10 (samples 4 and 7), 7 (samples 12 and 13), 4 (sample 23), 3 (sample 24), and 1 (sample 26), respectively. Analyses of the clay samples were conducted using bulk X-ray diffractometry. The identification of the mineralogical phases was made by comparing the Miller indices found in the samples with those of the International Centre for Diffraction Data.

For the archaeological material, our aim was to identify the reduction processes performed in each site (Geneste, 1991; Texier and Roche, 1995), through the succession of gestures and technical choices for the manufacturing and the techno-economic process, in order to describe associated cognitive skills. Cores allowed the identification of knapping methods by the observation of the hierarchy of flaking surfaces and the analysis of removal sequences (Despriée et al., 2018). For the heavy-duty component, we identified the volumetric processes, sizes and morphological results (Goren-Inbar and Sharon, 2006; Key et al., 2016; Herzlinger et al., 2017).

\section{RESULTS}

\section{Drilled cores C1 and C2}

The two cores that were drilled in 2005 are $48 \mathrm{~m}$ (C1) and $36 \mathrm{~m}$ (C2) long (Fig. 3), respectively. C1 was a few meters from locality CG1 (or "H" in Fig. 2 and 3), where the human calvarium was discovered; $\mathrm{C} 2$ was drilled $50 \mathrm{~m}$ northwest from C1, in the area of locality CG9. A normal geomagnetic polarity was recorded in both cores and has been interpreted as pertaining to the Brunhes chron (Muttoni et al., 2009). Although an overview of their composition was already reported by Manzi and colleagues (2010), here we describe the sedimentological succession of the two 




Figure 3. (color online) (a) Partial view of the area of Campogrande, which includes: the discovery site of the human fossil specimen and the various excavations and drillings performed in period 2001-2006. Some of them are also reported in (b) the correlation panel extending in a north-south direction and showing the stratigraphic relationships among the different units that have been recorded. The black ball in (b) indicates the projected stratigraphic position of the Palaeoloxodon antiquus $(\mathrm{P})$ within the deposits of trench $(\mathrm{T})$, corresponding to the clay layer in Figure 5 between units 10 and 11. (c) The marine oxygen isotope record from Lisiecki and Raymo (2005), with the inferred chronological position of the Ceprano human calvarium based on lithostratigraphical, geochemical, palynological, and geochronological data (Manzi et al., 2010). B, excavation test in the locality CG9; C1/C2, Core 1 and Core 2; H, site of discovery of the human calvarium (CG1); P, excavation, site of discovery of a partial skeleton of Palaeoloxodon antiquus; T, trench along the slope towards the Fosso della Manoviccia; W, stratigraphic witness above the present ground level (extension of locality CG9).

cores in combination with newly available evidence and focusing on the uppermost layers.

Both cores have a similar stratigraphy with four main units, named from the oldest to the youngest: A, B, C, and D. The lowermost unit A (about $9 \mathrm{~m}$ thick) is composed of marl deposits and may be tentatively ascribed to the TortonianMessinian (Centamore and Dramis, 2010), while the B and $\mathrm{C}$ units are attributed to LR1, and the unit D to LR2 (Fig. 3). An unconformity surface separates unit A from the overlying unit B (about $5 \mathrm{~m}$ thick), which is composed of a limestone breccia, suggesting deposition in a subaerial setting. The absence of volcanic materials suggests deposition before the beginning of the regional volcanic activity dated about $700 \mathrm{ka}$ (Fornaseri, 1985). Unit $\mathrm{C}$ is composed of lacustrine sediments and is separated from the underlying unit $\mathrm{B}$ by an unconformity surface. It is about $20 \mathrm{~m}$ thick and shows a transgressive-regressive trend, characterized by coarse and very-coarse carbonate sands (about $4 \mathrm{~m}$ thick) at the base, passing upward to muddy and sandy-muddy deposits (about $10 \mathrm{~m}$ thick), with interbedded thin layers of bioclastic material and a high concentration of organic matter. These features suggest a deposition of this unit in shallow water, close to the lake shoreline in a probable deltaic setting.

In the lower and upper portion of this unit, pollen assemblages suggest the continuous presence of a closed-canopy forest that requires temperate climatic conditions associated with interglacial periods. By contrast, the middle portion indicates an interval of increased aridity and lower temperatures that should correspond to a glacial period (Margari et al., 2018). Another discontinuity surface, detected at $14.7 \mathrm{~m}$ below the top of the core, separates the unit C from unit $D$. The sediments of unit $D$ are those in which the calvarium was discovered and are sterile from a palynological point of view (Margari et al., 2018); they indicate a 




Figure 4. (color online) The stratigraphic sections of site $\mathrm{P}$ during excavation; letters only indicate the different mud and silty-sand horizons alternating along the section. The samples for clay composition derive from units $\mathrm{A}$ and $\mathrm{H}$.

muddy-sand deposition in palustrine-lacustrine shallow water, upward replaced by fluvial deposits whose sedimentological characters are visible in the trench $\mathrm{T}$ of locality CG9. Moreover, in the fluvial deposits of unit D a partial skeleton of Palaeoloxodon antiquus was found in the excavation $\mathrm{P}$ (Fig. 3a).

The fluvial deposits at the top of $\mathrm{C} 2$ contain a leucitic tephra layer, originally $\mathrm{K}-\mathrm{Ar}$ dated to $385 \pm 20 \mathrm{ka}$ (Ascenzi and Segre, 1997a, 1997b), corresponding to the layer in C1 more recently ${ }^{40} \mathrm{Ar} /{ }^{39} \mathrm{Ar}$ dated to $353 \pm 4 \mathrm{ka}$ (Nomade et al., 2011). A remnant of this tephra layer occurs $30 \mathrm{~cm}$ above the clay layer where the calvarium was discovered and 1.0 $1.2 \mathrm{~m}$ below the top of the core $\mathrm{C} 1$. Its compositional character suggested to Nomade and colleagues (2011) a relationship with the volcanic activity of the Pofi field (from 410 to 354 ka; Frezzotti et al., 2007; Boari et al., 2009), an edifice occurring in the middle Latin Valley, just a few kilometres from Ceprano. The tephra layer is clearly visible in the outcropping section W (Fig. 3), where it appears to be truncated by an erosional surface, above which sandy-gravel deposits attributed to a braided fluvial system occur. These gravels and sands include an Acheulean assemblage that has been found in excavations of the stratigraphic witness $\mathrm{W}$ and test $\mathrm{B}$ (Fig. 3 and 6), both corresponding to the archaeological unit CG9A.
As for the age of the Ceprano calvarium, it has been suggested a chronology bracketed between 430 and $385 \mathrm{ka}$ (MIS 11; Manzi et al., 2010), in contrast to the original hypothesis of about 800-900 ka (Ascenzi et al., 1996, 2000). The chronology of the calvarium pointed out by Manzi and colleagues (2010) was obtained through a multidisciplinary approach, which included stratigraphicsedimentological analysis, palynological data, geochemistry, soil-micromorphology, taphonomy, and the archaeological evidence (see also Di Vincenzo et al., 2017; Margari et al., 2018). The date bracketed between 430 and $385 \mathrm{ka}$ is also consistent with the normal geomagnetic polarity recorded in the area (Muttoni et al., 2009) and with the age of $353 \pm$ $4 \mathrm{ka}$ ( $\pm 1 \sigma$ full external errors), obtained by Nomade and colleagues (2011; see also Pereira et al., 2018) by sampling the coarse-grained volcanoclastic layer above the clay containing the human specimen. Moreover, the clay layer where the calvarium was found is stratigraphically below the Acheulian levels occurring in the same area, namely in the localities CG9 and CG10 (Ascenzi et al., 1996, 2000; Manzi et al., 2001, 2010).

Another important aspect to be considered is the position occupied by the deposits of CG1 in the final filling phase of the Lirino Lake. Such phase is incompatible with a glacial period that would produce a sharp fall of fluvial base level, associated in turn with erosion. Conversely, there is no evidence of erosion at CG1, while we observe the conditions for the formation of accommodation space that was utilized by the lacustrine systems to aggrade and prograde, filling the basin. Coherent with these observations, data from the palynological analysis of samples from core C1 (Margari et al., 2018) suggest two different forest periods, separated by an interval of herb-dominated vegetation, which are both assigned to MIS 13 (interglacial phase). The erosional surface separating the unit $\mathrm{C}$ from unit $\mathrm{D}$ in the same core is attributed to MIS 12 (glacial phase), pointing out that the timing of deposition of the human calvarium in unit $\mathrm{D}$ is within MIS 11, as already hypothesized by Manzi and colleagues (2010).

We argue that the human calvarium was deposited during the period in which the Lirino Lake was definitively filled and when a change in depositional systems occurred, transitioning to a typical fluvial regime, as we describe below. This scenario is more consistent with an age close to $400 \mathrm{ka}$ (i.e., MIS 11), instead of 350 ka (i.e., MIS 10).

\section{Description of the trenches $P, T$, and $B / W$}

The excavation P (Fig. 3a and 4) occurs in the area where a partial skeleton of Palaeoloxodon antiquus was found. This section is about $20 \mathrm{~m}$ northwest from the trench T. The P section is $120 \mathrm{~cm}$ thick and characterized by clays at the bottom (unit A; Fig. 4) passing upward to alternating thin beds of ripple cross-laminated sands (units B, D, F, and H in Fig. 4) and mud (units C, E, and G in Fig. 4), which indicate transport of sediments as bed load and suspended load respectively. Both these kinds of deposit show a partial process of pedogenesis 
sw

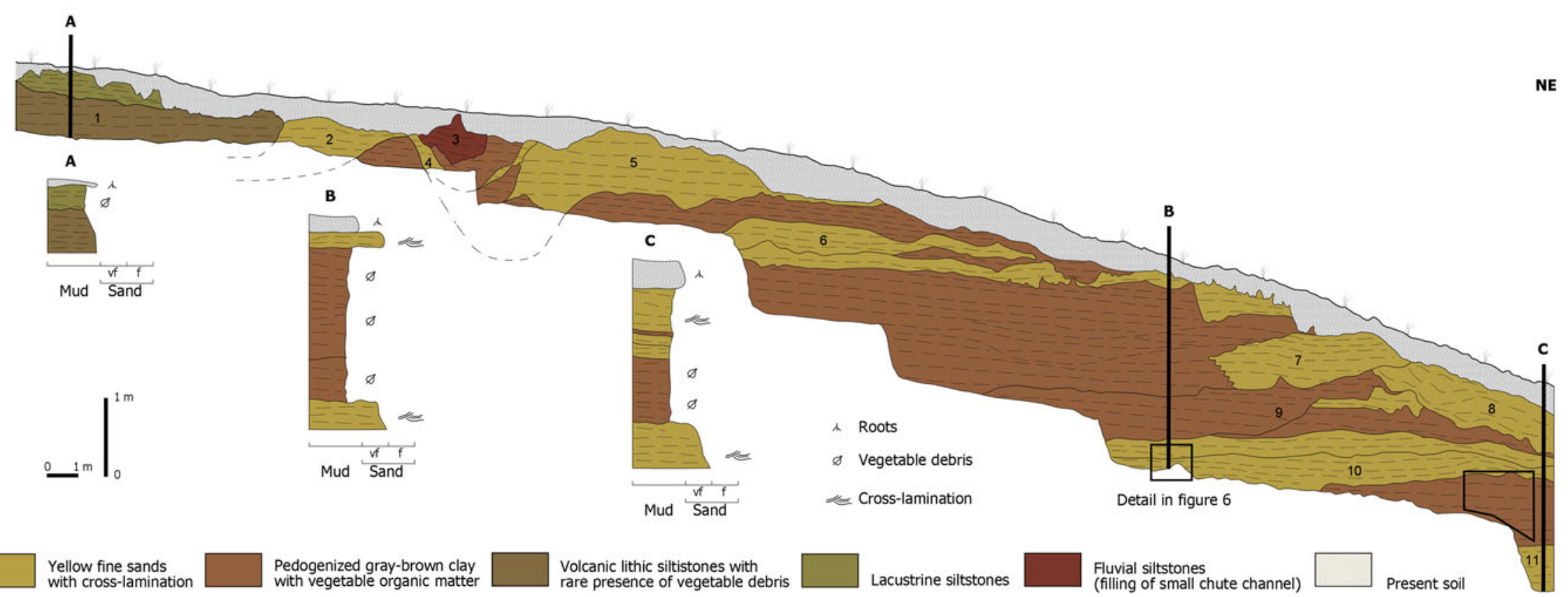

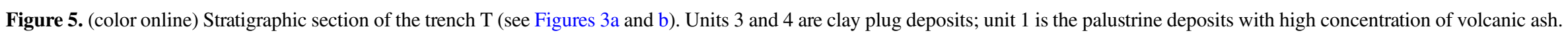

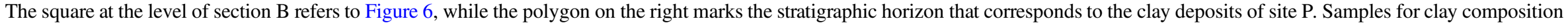
derive from units $1,3,4,7$, and 10 . 


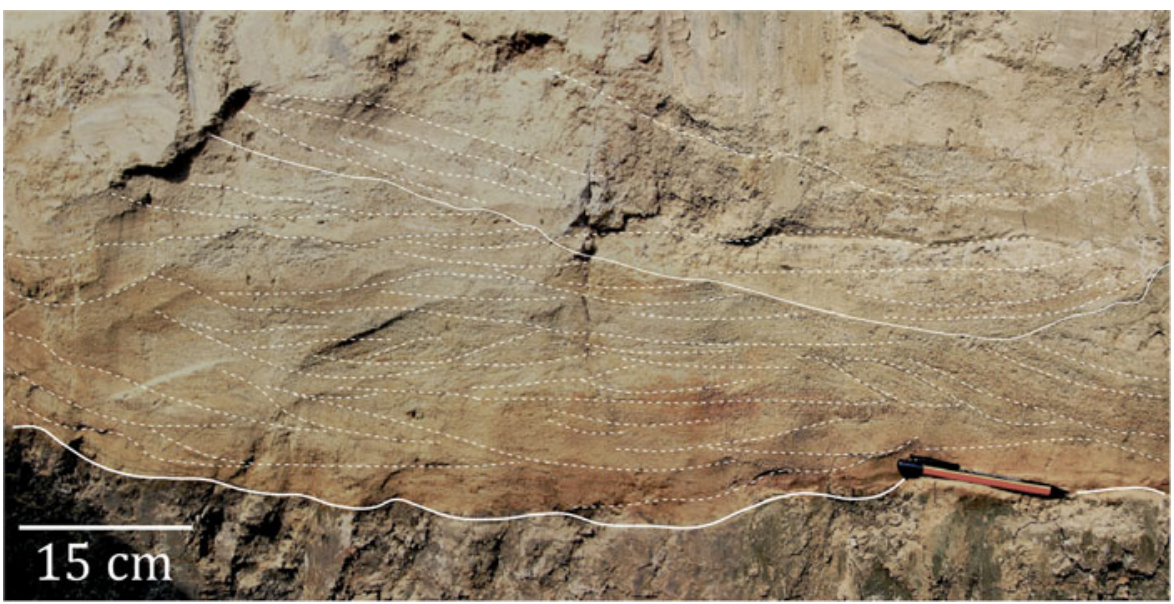

Figure 6. (color online) Detail of the section B in the trench $\mathrm{T}$ (as indicated in Figure 5), showing small and medium trough cross-lamination occurring at the base of the meandering fluvial channel.

with a paleosol profile characterized by a grayish brown clayey Bk horizon, mostly composed of expandable smectite clay, carbonate gray nodules, reduction zones, drab halos, and redoximorphic features (mottles; Calcic Vertisol; FAO, 2006). Rare bioclastic material, represented by fragments of pulmonata gastropoda occur in the clay layers. The set of these characters indicates that the entire sequence of sediments developed in an interglacial stage, with a climate characterized by marked seasonality in rainfall followed by dry conditions; this, in turn, is consistent with the assignments to MIS 11 of the clay where the calvarium was found.

The trench T (Fig. 3, 5, 6), about $3 \mathrm{~m}$ deep, is oriented $\mathrm{N} 40 \mathrm{E}$ and the whole deposit is tectonically tilted up to southwest. A stratigraphic panel of the trench (Fig. 5) indicates several depositional units with a clear fining-upward trend, which are bounded above and below by inclined erosional surfaces. In particular, these units (from 11 to 3 ) are comprised in the lower portion by yellow fine and very finegrained sands, showing planar and trough cross-lamination (Fig. 6), passing upward to pedogenized brown muddy deposits which are very rich in organic matter (Calcic Vertisol; FAO, 2006). Genesis of sand cross-lamination is related to the migration of bedforms as ripples and small dunes, with lee-side laminae dipping towards the south-southeast (N150E). The higher portion of the trench (southwest sector) is characterized by muddy deposits (units 1 and 2), with rare plant fragments and a high percentage of volcaniclastic detritus forming a clay plug.

From a stratigraphic point of view and based on the correlation among the measured sections and the cores $\mathrm{C} 1$ and $\mathrm{C} 2$, the deposits of the $\mathrm{P}$ section are equivalent to the deposits of unit 11 of trench $\mathrm{T}$ (Fig. 5). The comparison between the clay mineralogical samples (see Supplementary Material) indicates that those in $\mathrm{P}$ correspond to the clay interval of the unit 11 of the trench T. They show a high percentage of clay minerals, essentially chlorite and montmorillonite, illite, and kaolinite, and a low percentage of quartz. The presence of montmorillonite stratified with illite and chlorite and the absence of sialic phases suggests strong leaching for a long time produced this clay unit. Moreover, the presence of the chlorite could suggest an alteration process of basic volcanic rocks rather than acid rocks. Calcite and feldspathoids are absent. On the contrary, the younger samples taken from other depositional units (units 10, 7, 4, 3, and 1; Fig. 5) show that quartz is the most abundant mineral followed by plagioclase, calcite, and clay minerals like montmorillonite, illite, chlorite, and kaolinite. Such an assemblage suggests a different origin of these minerals, probably from the erosion and the alteration of carbonate rocks, as well as terrigenous siliciclastic sedimentary rocks. A possible change in the drainage area of the fluvial system can be hypothesized in order to explain this variation in mineral composition. This could have been caused by tectonic activity. As a result, the change from unit 11 and the following ones (from unit 10 to 1) should represent a discontinuity surface connected with the final filling of the Lirino Lake. During this last phase, the volcaniclastic layer was deposited; either it is referred to an eruptive phase of the Roccamonfina volcano (Ascenzi and Segre, 1997a, 1997b) or to the Pofi volcano (Nomade et al., 2011; Pereira et al., 2018).

Although of limited thickness and extent, the deposits of trench B and witness W (Fig. 3 and 7) is composed of sandy gravel and gravelly sand, which are placed above the tephra layer clearly visible in the outcropping section W (Fig. 7). These layers form terraced alluvial deposits corresponding to the Colfelice Synthem in the new Italian geological map at 1:50,000 scale (Sheet 402, Ceccano; Centamore and Dramis, 2007). On the basis of the outcrops occurring in surrounding areas (including the localities CG9 and CG10), these deposits show a tabular geometry and are internally characterized by sheets of structureless or flat-bedded imbricated gravels, associated with medium-scale trough or planar cross-bedding sandy gravels, which form lenticular or tabular sets (10 to $50 \mathrm{~cm}$ thick). Such deposits are organized to constitute depositional units (from 50 to $100 \mathrm{~cm}$ thick), exhibiting a fining-upward trend. Finer-grained 


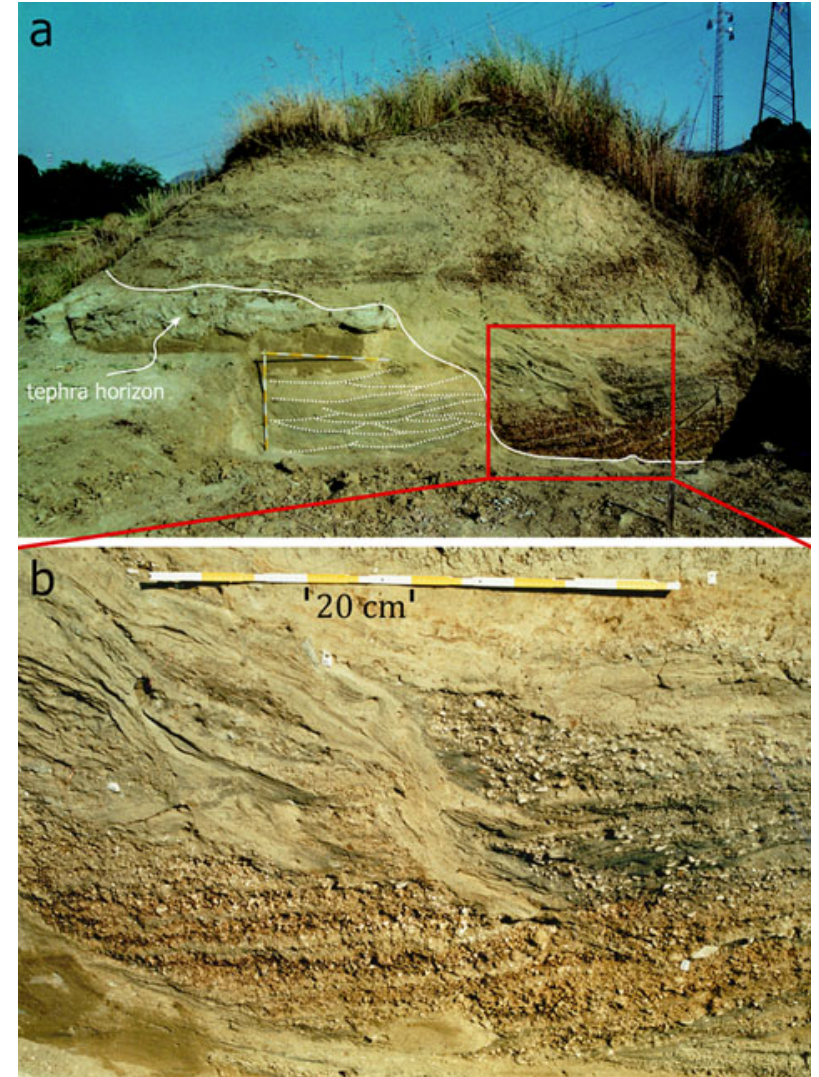

Figure 7. Remnant of sand and sandy-gravel fluvial deposits attribute to a braided stream, as they are now visible in the witness W. Note the trough cross bedding related to (a) 3-D bedforms and (b) the detail of the scour filled with gravel deposits. Yellow and white notches are $10 \mathrm{~cm}$ long. The tephra horizon (see label) is the layer that was originally K-Ar dated to $385 \pm 20 \mathrm{ka}$ (as reported by Ascenzi and Segre [1997a, 1997b]). (For interpretation of the references to color in this figure legend, the reader is referred to the web version of this article.)

sediments (essentially silt) are poorly or not preserved, suggesting therefore high-energy flows responsible for the deposition of sand and gravels. Locally, ripple cross-laminated sands occur at the top of the depositional sequence.

\section{Interpretation of the deposits}

The stratigraphic and sedimentological features of the trench deposits $P$ and T recorded at Campogrande (locality CG9) can be interpreted as the products of sedimentation in a floodplain environment with a low topographic gradient in which a meandering channel occurred. The stack of laterally accreted depositional units described above, shows a clear fining-upward trend and an upslope decrease in the bed form size, which can be interpreted as the expression of a point bar lateral migration. This migration was strictly related to the alternating periods of high- and low-flow stages, which generally characterize flood events (Allen, 1965; Bridge, 2003, 2006; Collinson et al., 2006). The deactivation and closure of this fluvial channel is recorded by the presence of a clay plug (unit 1 in Fig. 5) in the upper portion of the trench, while laterally a thin palustrine whitish muddy deposit occurs, rich in volcanic ash.

The cause of channel deactivation may be due to a possible avulsion process. Several mechanisms can be considered responsible of this process involving tectonic, climate, or more simply a decrease for water supply that limited the volume of the transported sediment into the channel. At present, considering the small investigated area, no tectonic data are available that justify a possible influence of the tectonic movements on channel deactivation, although this is not ruled out. The process can be related to a climatic change that, in turn, produced a change in the fluvial regime. Based on the stratigraphic relationships between the trench deposits and those of the $\mathrm{C} 1$ and $\mathrm{C} 2$ cores, and considering the age constraints, we argue that such climatic change can be reasonably ascribed to the warm/cold transition between MIS 11 and MIS 10. This hypothesis is also indirectly supported by the fact that the sediments in which the calvarium was recovered were deposited in an interglacial phase (MIS 11; see above), with an increase of volcanic activity shortly before the Ceprano basin was filled. The fluvial system with sinuous channels that characterized the Campogrande area between 460 and $380 \mathrm{ka}$ (Manzi et al., 2010) was one of the causes for the filling of the Lirino lacustrine basin.

The sand and gravel deposits of trench B and witness W (Fig. 3 and 7), occurring above those described in trench $\mathrm{T}$, show many characters that we interpret as the product of braided river depositions. Trough and planar cross bedding are related to the migration of small and medium dunes within shallow laterally unstable channels, which internally develop longitudinal and transverse bars. The absence of fine-grained sediments suggests a vigorous bed load transport during flood events that are able to move the coarsest particles, giving rise to recognized bedforms. Paleocurrents also indicate a transport of the sediments towards the southern sector, suggesting that the braided river stretched in a north-south direction, having a probable width of about $500 \mathrm{~m}$, which included the areas of both Colle Avarone and Campogrande. Lower Paleolithic artefacts were found in the deposits of $\mathrm{B}$ and $\mathrm{W}$, with a heavy-duty component and evidence of core technologies (assemblages from the archaeological unit CG9A.

\section{Archaeological assemblages at CG9 and CG10}

The archaeological material described here comes from the localities labelled CG9 and CG10 (Fig. 2). This material is younger than the human calvarium in CG1, stratigraphically lying above the tephra layer dated to $385 \pm 20 \mathrm{ka}$ (Ascenzi and Segre, 1997a, 1997b) and $353 \pm 4$ ka (Nomade et al., 2011). The greater part of this material was discovered by one of us (I. Biddittu) during different systematic surveys, mostly after ploughing, while another part was unearthed during the 2001-2006 excavations (namely, in the excavations of test $\mathrm{B}$ and witness $\mathrm{W}$ ). At present, all the material is stored at 
the Museo Preistorico "Pietro Fedele" in Pofi (Frosinone, Italy).

The CG9 Acheulean material comes from an archaeological unit named CG9A (originally "CG9 superiore," or upper) and corresponds to levels that are visible in the witness $\mathrm{W}$ and have been excavated in the test B (Fig. 3 and 7). The CG10 material comes from three different units, respectively named CG10A (originally "CG10 superiore," or upper), CG10B (originally "CG10 intermedio," or intermediate), and CG10C (originally "CG10 inferiore," or lower). In the CG10 locality, no stratigraphic and sedimentological analyses have been carried out so far, but preliminary data indicate that CG10A is comprised of limestone gravels and augitic sands, CG10B of clays, and CG10C of sands with volcanic material.

\section{CG9A or "superiore"}

The series totals one, thick, bifacial core and 11 bifaces, on limestone and flint, ranging in size from 80 to $220 \mathrm{~mm}$ long, subdivided as follows.

(a) Bifaces completely or partially worked, symmetric in cross section, made by series of removals, large or short $(n=2)$. The tip is curved in one case (Fig. 8a; inventory no. M4150).

(b) Plano-convex partial bifacial tools with sometimes a back (from a flake?) with a pointed or round tip. Final retouches cover the two cutting edges shaped on half the piece $(n=3)$.

(c) On asymmetric tools, the flattest surface is shaped by large removals that make the whole face thinner, while the opposite convex face is managed by series of removals limited to the upper half and the periphery of the tool $(\mathrm{n}=6)$.

\section{CG9B or "intermedio"}

Only three flint bifaces were collected. The main features are common to the pieces of the other localities. They are made on a flake and pebble; the shaping covers a large part of one surface and especially the periphery and the extremity made by more removals (Fig. 8b; inventory no. M4158).

\section{CG10A or "superiore"}

A dozen pieces can be described as cores and/or choppercores. They are made on small flint nodules/pebbles (50 mm long) and limestone oval and quadrangular pebbles of bad quality (Fig. 9a and b; inventory no. M7552 and M7868). The debitage always uses the natural morphology of the pebble or the nodule. It is orthogonal or unifacial unipolar (on the largest face or on the core edge). The number of removals is limited and products are irregular and frequently hinged. No preliminary preparation of the core is visible. Platforms are cortical or use the previous removals.

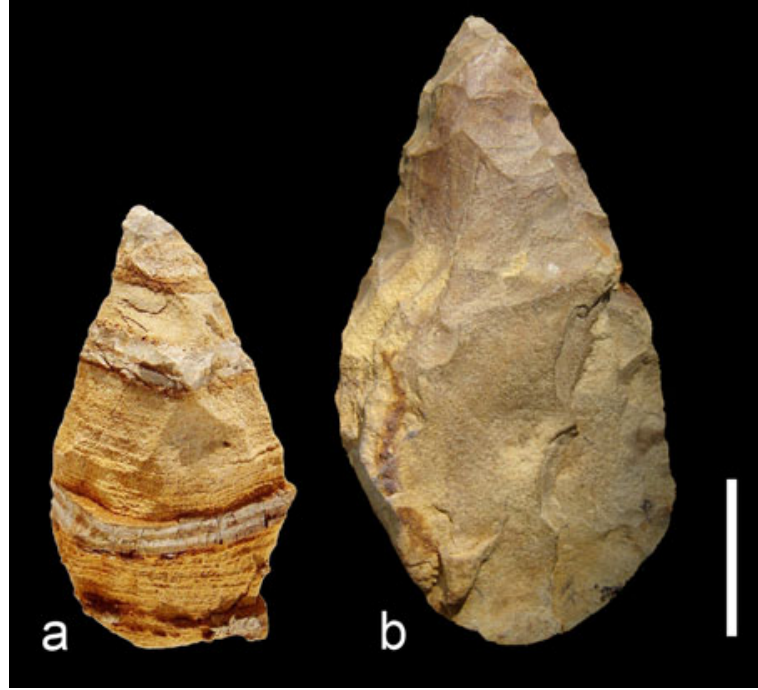

Figure 8. (color online) Campogrande area, CG9 locality (bifaces). (a) Unit CG9A, inventory no. M4150, biface in laminated limestone with interposed levels of silex; (b) unit CG9B, inventory no. M4158, biface in flint on a flake. Scale bar is $50 \mathrm{~mm}$.

The series includes 22 heavy-duty tools, including mainly partial bifacial tools. They are only made on limestone. Three categories can be distinguished:

(a) A thick, pointed scraper (rabot-type) made by deep and large removals on a small part of the periphery of a broken limestone pebble $(n=1)$.

(b) Elongated, plano-convex bifaces $(n=5)$ on badly preserved limestone (Fig. 10a; inventory no. M7539). These tools are among the longest ones, around $200 \mathrm{~mm}$. Some cortical residues suggest that the support could be a flat and elongated pebble. The whole bifacial volume is managed by one series of invasive removals on the two faces. Some removals are hinged. The

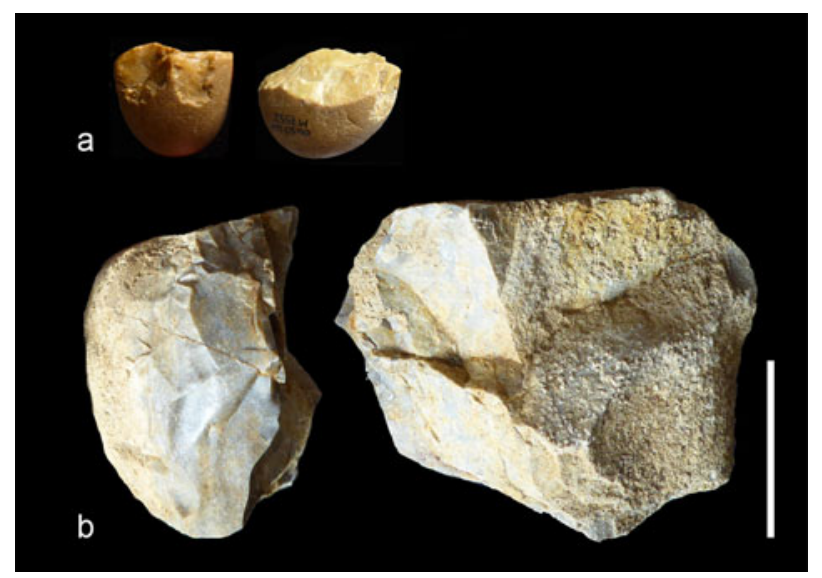

Figure 9. (color online) Campogrande area, CG10 locality (cores). (a) Unit CG10A, inventory no. M7552, small core on a flint pebble, where the debitage is on two orthogonal faces; (b) unit CG10A, inventory no. M7868, cores on flint pebbles with one or orthogonal flaking surfaces. Scale bar is $50 \mathrm{~mm}$. 


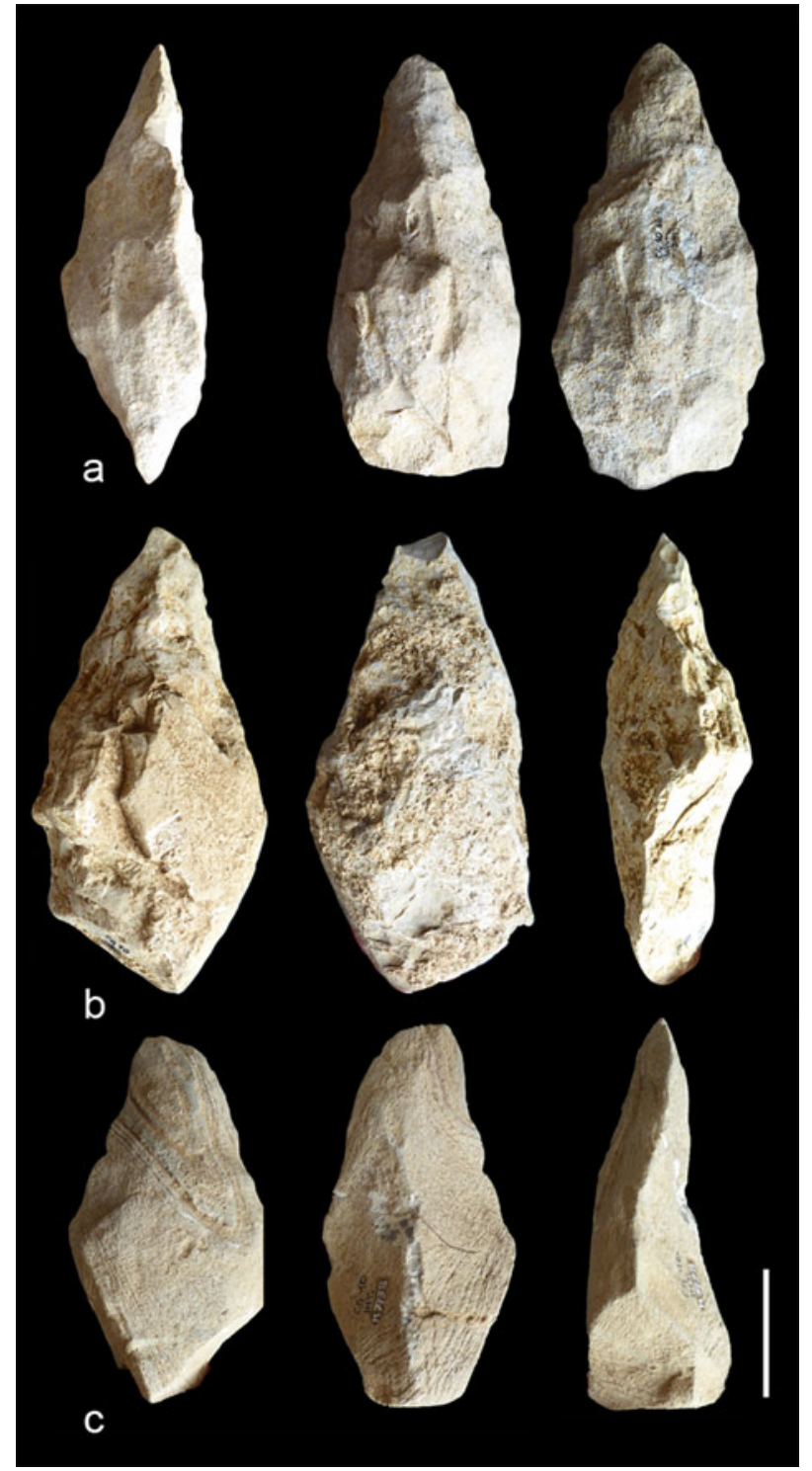

Figure 10. (color online) Campogrande area, CG10 locality (bifaces). (a) Unit CG10A, inventory no. M7539, asymmetric, elongated biface on limestone with whole shaping; note that the middle part of the tool is the thickest, removals cover the two faces, and edges are sinuous. (b) Unit CG10A, inventory no. M7895, partial bifacial tool on a limestone flake. Note that one series of removals is invasive and flat on one face and abrupt on the opposite face, the edges are sinuous, and a cortical back is preserved. (c) Unit CG10B, inventory no. M7738, limestone partial bifacial tool possibly on a flake, where the pointed upper part is worked with thin removals. Scale bar is $50 \mathrm{~mm}$.

shaping is alternate or face-by-face when visible. The edges are never rectified by retouches and they stay sinuous. The base of the tool is shaped by convergent removals (giving a thin cutting edge) or sometimes left unworked (back or natural round cortical base). The tip is always thin, and the shape, made by small removals, is included into the general shaping. The maximum thickness of the tool is on the proximal or the middle part of the biface. The cross section is always asymmetric, whereas the tool general form is symmetric.

(c) Partial bifacial tools on limestone $(n=16$; Fig. 10b; inventory no. M7895). This category is more diversified than the previous one, in size and mode of shaping, with short and elongated pieces (from 110 to $210 \mathrm{~mm}$ ). The support is a flake for most of the tools. The shaping concerns mainly the upper part of the tool, covering the two faces or only the periphery. In some cases, only the tip and one edge are worked, opposing the cutting edge to a back or a cortical side. The tip is pointed or round and made by small or large removals related to the shaping process of the lateral cutting edge(s). The base is always cortical, with or without a natural back. The cross section is plano-convex. The flattest face is covered either by large removals or by short removals limited to the upper part of the face. The opposite surface indicates series of semi-abrupt removals, rarely rectified by a final series of short removals and retouches. The cutting edges are consequently always sinuous. Removals are frequently hinged. One piece shows a longitudinal "coup de tranchet." Another piece shows some transversal removals on the tip (perhaps due to use or resharpening). Most of the tools are asymmetric partial bifacial tools on limestone and the type of support seems to have played a major role, producing opposing flakes with a minimum shaping to an elongated pebble with a most invasive shaping. One series of removals characterize all the tools without final retouches giving sinuous edges. Besides the elongated bifacial pointed tools, some other bifacial tools preserve a backed edge as a main distinctive feature.

\section{CG10B or "intermedio"}

Except some cores on small flint nodules (less than $50 \mathrm{~mm}$ long) for the production of a few small flakes, the series is composed of both a heavy-duty and a light-duty component. The light-duty component is composed of a micro-biface on a limestone pebble, a micro convergent pebble-tool, and a point on a micro-flint nodule (30 to $50 \mathrm{~mm}$ long). They are minimally shaped by few unifacial and bifacial removals, which do not really modify the form of the pebble (Fig. 11a; inventory no. M9630). The heavy-duty tools are composed of one rabot, a thick scraper on a limestone half-pebble, and three bifaces in siltstone or quartzite (Fig. 10c; inventory no. M7738). The bifaces are mainly partially shaped. One shows a thick base. The shaping concerns the whole volume. Removals are abrupt on the two faces managed by an alternate shaping. The cutting edges are sinuous and without final retouches, while particular attention was paid in shaping the tip (more removals). The cross section is asymmetric. For the others, they are made on large flakes. The shaping is partially invasive, alternate, or face-by-face. The cross section remains symmetric. Removals are reduced on the base. 


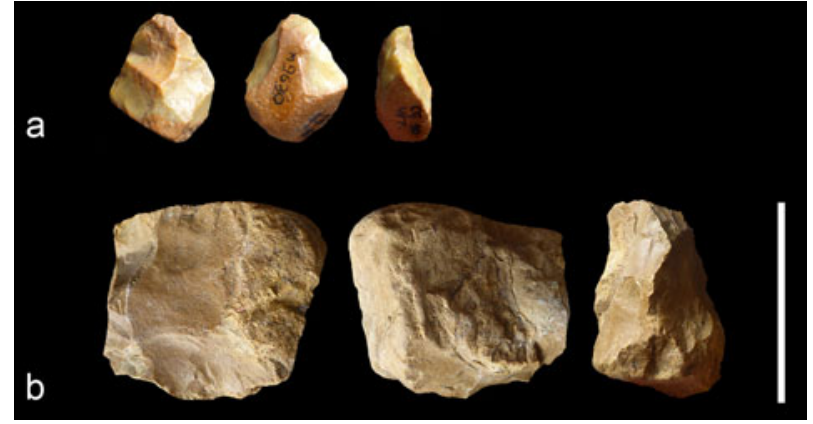

Figure 11. (color online) Campogrande area, CG10 locality. (a) Unit CG10B, inventory no. M7582, thick and asymmetric flint microlithic bifacial tool made by some removals. (b) Unit CG10C, inventory no. M10038, core on a flint nodule with small bifacial removals on part of the periphery. Scale bar is $50 \mathrm{~mm}$.

\section{CG10C or "inferiore"}

No bifaces were found in this unit. Cores $(\mathrm{n}=15)$ are made on small flint and quartz nodules/pebbles (Fig. 11b). They indicate an orthogonal or multidirectional debitage adapted to the form of the nodule or pebble, a transversal debitage (slices) on thick pebbles, and a bifacial debitage with asymmetric flaking surfaces. Removals are short, deep, and hinged due to the lack of preparation of the cores. Cores are left unexhausted due perhaps to inaccurate angles to continue flaking.

\section{Interpretation of the archaeological assemblages}

The Ceprano area represents a key site to describe in detail traditions after the end of MIS 12, based on various localities clustered in a small area. The quantity of artefacts collected in the CG localities is lower than at other nearby Middle Pleistocene sites, such as Colle Avarone (CA) and Lademagne (Biddittu and Segre, 1977; Biddittu et al., 2012). Comparisons, however, indicate common features of raw materials and technology in the CA and CG localities.

The CG series artefacts are mainly made on fine-grained limestone, associated with flint, quartzite, and quartz. The limestone is generally poorly preserved with smooth edges and breccia, whereas flint, quartzite, and quartz are fresher. Use of types of raw materials differs between the core technology and the shaping. It is likely due to the sizes of the available nodules and pebbles. Limestone is the main raw material for the bifaces and the heavy-duty component, completed by quartz, quartzite, and flint, possibly because limestone exists in various qualities as small and large pebbles on and in the surroundings of the localities. For the debitage, flint, then quartz and fine-grained limestone pebbles, are reemployed. Flint exists mainly under the form of small nodules; thus, it is mainly used for flaking except for CG10B and CG9B, where some bifaces are made from large flint supports.

The core technologies at the CG localities record the same technological features. Cores are small, on small flint nodules or pebbles of other materials. They do not indicate a preparation. The debitage is minimal and does not modify the form of the support. Cores are never exhausted. The debitage is performed on one or two faces, or orthogonal with mainly unipolar or crossed removals. Some round pebbles have been flaked by "slices." There is no evidence of Levallois core technology in the CG localities, in contrast to the MIS 11/10 Italian site of Guado San Nicola, where the Levallois is represented by cores and flakes (Peretto et al., 2016). The CG core technology resembles the debitage at Torre in Pietra (layer m; Piperno and Biddittu, 1978; Villa et al., 2016) and La Polledrara (Anzidei et al., 2012) made on small flint nodules.

The heavy-duty tools are the main component of the CG series. Three types of heavy-duty tools are common to the series but in different ratios: (1) elongated bifaces; (2) partial bifacial tools; and (3) heavy "scrapers" and "rabots." The mode of shaping is not linked to the type of raw material since the bifaces made on flint share common technological features to the tools on other kinds of stones. On the other hand, the mode and intensity of shaping is necessarily consistent with the raw material and the shape of the original pebble. The partial bifacial tools are mainly made on flakes (easily identified) considered as preformed, which do not ask for a large management. Categories are not stages in a shaping process but distinct types of tools with specific purposes and sizes, although all are asymmetric tools in cross section. While bifaces show a symmetrical and elongated morphology, the partial bifacial tools are shorter and frequently asymmetric and transverse, although in a few cases they may have an elongated form. The bifaces are the longest pieces (around $200 \mathrm{~mm}$ ). Some partial bifacial tools allow a resharpening since a limited part of the upper part of the tool is shaped by additional sectors. In contrast, most of the bifaces do not allow this resharpening without modifying the whole volume.

The CG localities offer the opportunity to observe technological trends and variability in a regional perspective and describe lithic series from close time periods in a small territory. The mode of shaping performed at Campogrande indicates both common and distinct features with some MIS 11-9 Italian sites in terms of shaping processes and morphological results. For instance, at Torre in Pietra, layer "m", dated to MIS 10 (Villa et al., 2016), most of the bifaces made from limestone or flint show an asymmetric cross section. The upper part is shaped without modifying the pebble form. The tip is pointed, and the base is left cortical. The shaping does not allow a resharpening. They closely resemble many of the CG bifaces. Equally, at Guado San Nicola, assigned to MIS 11/10 (Peretto et al., 2016), bifaces total $3-4 \%$ of the series, made on flint and rarely silicified limestone, slabs, and some flakes. The raw material does not influence the mode of shaping, which provides asymmetric pieces. We observe a careful shaping of the tip with final retouches and a limited technical investment. The base is left cortical. Finally, at the more recent site of Castel di Guido, in MIS 9 levels (Radmilli and Boschian, 1996; Boschian and Saccà, 2015), bifacial tools on fragments of Palaeoloxodon antiquus bones and stone pebbles indicate common shaping strategies 
at the site, whatever raw material is used, and common features with the Campogrande series.

\section{DISCUSSION}

Geological fieldwork and analyses coupled with the study of Paleolithic assemblages from localities close to the CG1 locality (the site where the Ceprano calvarium was discovered in 1994) enrich our understanding of human evolution in Europe during the second half of the Middle Pleistocene.

\section{Combining sedimentological and archaeological data}

The new and detailed stratigraphic and sedimentological data collected at Campogrande have provided further information on the history of the Lirino Lake, where the Ceprano calvarium was found. Our analysis of the stratigraphy of this area (c.f., Manzi et al., 2010; Margari et al., 2018) reinforces the conclusion that the hominin specimen was deposited in fluvial floodplain, constituting the final filling of the Lirino Lake.

These data, together with a series of chronological constraints (including $\mathrm{K} / \mathrm{Ar}$ and Ar/Ar dates, paleomagnetism, and a combination of paleoenvironmental data) indicate that the age of the clay layer where the human specimen was found must be reasonably ascribed to MIS 11. This period was characterized by increasing volcanic activity in the area, as testified by the composition of the sediments. Thus, the K/Ar date of $385 \pm 20 \mathrm{ka}$ (Ascenzi and Segre, 1997a, 1997b) and the Ar/Ar date of $353 \pm 4$ ka (Nomade et al., 2011), which have been recorded in deposits at the top of the two drilled cores, $\mathrm{C} 1$ and $\mathrm{C} 2$, respectively, represent a terminus ante quem for the deposition of the human calvarium. The overlying sandy-gravel deposits forming the stratigraphic witness W (Fig. 3 and 7) and recorded also in the excavation test B (Fig. 3) are younger. They both include Paleolithic material with bifaces (archaeological unit CG9A), for which the dates at the top of $\mathrm{C} 1$ and $\mathrm{C} 2$ provide a terminus post quem.

The different localities of the Ceprano basin with lithic artefacts (Fig. 2) are scattered in a small area. Chronological data indicate that these sites and related archaeological assemblages are penecontemporaneous, allowing a comparison of technological behaviours after MIS 12, perhaps with the exception of the unit CG10C, which is characterized by flint and quartzite nodules/pebbles, with no bifaces, and appears more ancient from a stratigraphical point of view.

In general, the Campogrande series attest the occurrence of common regional trends of bifaces and bifacial tools with recurrent features, usually of large size (ranging in length from 50 to $260 \mathrm{~mm}$ ), while technological strategies are common to other Italian sites. These trends in tool kits could indicate a network of connected sites along fluvial systems in the basin, documenting the use of abundant, available, local, raw materials. Future analyses of bone assemblages will help to understand type of sites, subsistence activities, and possible networks.

Large retouched fragments of bones of large mammals at most of the localities suggest affinities with other sites in central Italy, such as Fontana Ranuccio, Castel di Guido, Torre in Pietra, and La Polledrara di Cecanibbio (Biddittu and Segre, 1980; Anzidei et al., 2012; Boschian and Saccà, 2015). This could explain why the core technologies exhibit minimal flaking aimed at rapidly producing useful flakes during shortterm occupations. A heavy-duty component is also present occasionally and is not clearly explained by the stone availability. The quantity of flakes pointing to a shaping process in situ is often small and it is consequently difficult to investigate the status of these large tools. They could be mobile pieces moving between sites or expedient tools worked for the activities performed on each site.

\section{Earliest and later Europeans}

The still scanty fossil evidence of archaeological assemblages without bifaces - characterized by a heavy-duty component of pebble tools, cores, and flakes-includes the following sites: Atapuerca-Sima del Elefante (Carbonell et al., 2008) and other sites near Orce, Spain (Toro-Moyano et al., 2009); Hérault, France (Crochet et al., 2009); and Arce, Colle Marino, Castro dei Volsci (Biddittu, 1984), and Pirro Nord (Arzarello et al., 2009), Italy. The assemblages of these early Lower Paleolithic sites indicate that scattered hominin settlements occurred in southwestern Europe during the late Early Pleistocene, probably earlier than 1.2 Ma.

The apparent absence of bifacial technology persists after 1.0 Ma. At the same time, discoveries in Spain, Italy, France, and England testify to the prompt onset before $500 \mathrm{ka}$ of technologies that may be referred to as "Acheulean," namely at Notarchirico, Italy (610-670 ka; Piperno, 1999; Lefevre et al., 2010; Pereira et al., 2015), Arago in southern France (around $550 \mathrm{ka}$, levels $\mathrm{P}$ and Q), and La Noira, in central France (around $700 \mathrm{ka}$, lower unit, stratum a; Barsky and Lumley, 2010; Barsky et al., 2013; Moncel et al., 2013; Falguères et al., 2015). Several sites along the paleo-Bytham in England yielded similar industries (Moncel et al., 2015; Voinchet et al., 2015). In contrast, the recent discovery of La Boella in Spain (Vallverdu et al., 2014), with bifacial tools dated to $1 \mathrm{Ma}-900 \mathrm{ka}$, reduces the chronological gap between Asia and Europe, raising questions as to the origin of the emergence (local or introduced?) of bifacial technology in the continent. In this framework, technological features of the earliest bifaces and lack of sites with evidence of a local emergence suggest the introduction of this technology on a cores-and-flakes substratum (Moncel et al., 2013).

The number of sites between $1 \mathrm{Ma}$ and $500 \mathrm{ka}$ suggest a low density of population, perhaps reflecting the isolation of small, mobile hominin groups, unable to maintain social networks or to occupy permanently the same area; this observation might explain the technological diversity between bifacial and non-bifacial industries (Moncel and Schreve, 2016). Before $500 \mathrm{ka}$, hominins are inclined to occupy 
marginal areas only in favourable environments, especially in the north of the continent. Latitudinal climatic gradients are consistent with the persistence of occupations in the south during periods of climatic deterioration that affected northern and central regions (Moncel et al., 2016). These climatic oscillations regularly forced hominins to retreat, expand, or even disappear from the region.

A large-scale expansion over Western Europe of Acheulean assemblages occurs after the cold phase of MIS 12, when various regional traditions were developing in both the north and south of Europe (Nicoud, 2013; Moncel et al., 2015; Ashton and Scott, 2016). The period of MIS 11-9 is thus a second crucial period, recording evidence of behavioural changes towards the early Middle Paleolithic, such as more complex and standardized core technologies, organized hunting, or changes in land use patterns (Moncel et al., 2016). Early fire control (Roebroeks and Villa, 2011) could have contributed to new hominin abilities to expand territories and modify their behaviour. After $500 \mathrm{ka}$, diversity of technological behaviours again characterizes the industries, with or without bifacial tools, but this diversity is based on more numerous assemblages, which allow the identification of these trends. Changes in climate cycles, in demography, and in density of occupations could have influenced these behavioural changes, favouring the emergence of regional traditions, demographic expansion and genetic exchanges (growth and regular adaptation without demographic discontinuities), as well as new skills exemplified by more or less rapid processes of population dynamics and cultural changes (Grove, 2016; Moncel and Schreve, 2016; Moncel et al., 2016).

The archaeological data from the Campogrande localities indicate that a kind of regionalization of archaeological traditions occurred at Ceprano-Campogrande after MIS 12. This seems related to the process of regionalization that involved both the north and the south of Europe (Ashton et al., 2008; Scott and Ashton, 2011; Ashton and Lewis, 2012; Fontana et al., 2013; Brenet et al., 2014; Garcia-Medrano et al., 2015; Ashton and Scott, 2016) and seems resulting from a combination of some different elements: (1) the extended climate stability after the coldest event of MIS 12; (2) the occurrence of technological shifts that were deeply rooted in previous traditions; and (3) a possible significant increase in human population density (Premo and Hublin, 2009; Moncel et al., 2012; Kleinen et al., 2014; Wisniewski, 2014; Limondin-Lozouet et al., 2015; Lamotte and Tuffreau, 2016; Moigne et al., 2016).

\section{SUPPLEMENTARY MATERIAL}

The supplementary material for this article can be found at https:// doi.org/10.1017/qua.2019.52.

\section{ACKNOWLEDGMENTS}

After the discovery of the human fossil calvarium near Ceprano (FR) in 1994, field activities and related researches in the area of
Campogrande have been authorized by the Soprintendenza A.B.A. e P. per le province di Frosinone, Latina e Rieti (formerly Soprintendenza Archeologica del Lazio), which we gratefully acknowledge. Both excavations and paleoenvironmental analyses were performed within the framework of the project "The Ceprano Calvarium and Its Environment," which received grants attributed to one of us (G. Manzi) by the Sapienza University of Rome; we thank all the colleagues and students that have been involved in this project, including Fabio Parenti, for his support in recording the topography of the Campogrande area, and Veronica Munzi, who helped to collect and analyse part of the sedimentological data presented and discussed in this paper. The study of the archaeological record was financially supported by funding from the National Museum of Natural History, Paris, France: Acheulean in volcanic areas in Italy (Action Transversale du Museum). We are also grateful to the Editors (Nicholas Lancaster, Senior Editor, and Tyler Faith, Associate Editor) and the anonymous reviewers of Quaternary Research, for their extremely helpful criticisms and suggestions.

\section{REFERENCES}

Agustí, J., Blain, H.-A., Cuenca-Bescós, G., Bailon, S., 2009. Climate forcing of first hominid dispersal in Western Europe. Journal of Human Evolution 57, 815-821.

Allen, J.R.L., 1965. A review of the origin and characteristics of recent alluvial sediments. Sedimentology 5, 89-191.

Anzidei, A.P., Bulgarelli, G.M., Catalano, P., Cerilli, E., Gallotti, R., Lemorini, C., Milli, S., Palombo, M.R., Pantano, W., Santucci, E., 2012. Ongoing research at the late Middle Pleistocene site of La Polledrara di Cecanibbio (central Italy), with emphasis on human-elephant relationships. Quaternary International 255, 171-187.

Arzarello, M., Marcolini, F., Pavia, G., Pavia, M., Petronio, C., Petrucci, M., Rook, L., Sardella, R., 2009. L'industrie lithique du site Pléistocène inférieur de Pirro Nord (Apricena, Italie du sud): une occupation humaine entre 1,3 et 1,7 Ma. L'Anthropologie 113, 47-58.

Ascenzi, A., Biddittu, I., Cassoli, P.F., Segre, A.G., Segre Naldini, E., 1996. A calvarium of late Homo erectus from Ceprano, Italy. Journal of Human Evolution 31, 409-423.

Ascenzi, A., Mallegni, F., Manzi, G., Segre, A.G., Segre Naldini, E., 2000. A re-appraisal of Ceprano calvaria affinities with Homo erectus, after the new reconstruction. Journal of Human Evolution 39, 443-450.

Ascenzi, A., Segre, A.G., 1997a. Discovery of a Homo erectus calvarium at Ceprano, central Italy. L'Anthropologie 35, 241-246.

Ascenzi, A., Segre, A.G., 1997b. Resti di cranio umano del Pleistocene medio-inferiore a Ceprano. Rendiconti Lincei Scienze Fisiche e Naturali 8, 39-67.

Ashton, N., Lewis, S.G., 2012. The environmental contexts of early human occupation of northwest Europe: the British Lower Palaeolithic record. Quaternary International 271, 50-64.

Ashton, N., Lewis, S.G., Parfitt, S.A., Penkman, K.E.H., Russell Coope, G., 2008. New evidence for complex climate change in MIS 11 from Hoxne, Suffolk, UK. Quaternary Science Reviews 27, 652-668.

Ashton, N., Scott, B., 2016. The British Middle Palaeolithic. Quaternary International 411, 62-76.

Barsky, D., de Lumley, H., 2010. Early European Mode 2 and the stone industry from the Caune de l'Arago's archeostratigraphical levels “P." Quaternary International 223, 71-86. 
Barsky, D., Garcia, J., Martínez, K., Sala, R., Zaidner, Y., Carbonell, E., Toro-Moyano, I., 2013. Flake modification in European Early and Early-Middle Pleistocene stone tool assemblages. Quaternary International 316, 140-154.

Biddittu, I., 1974. Giacimento pleistocenico ad amigdale acheuleane nel territorio di Ceprano (FR). Memorie dell'Istituto Italiano di Paleontologia Umana 2, 61-67.

Biddittu, I., 1984. Le più antiche industrie del Paleolitico inferiore del Lazio. In: Atti della XXIV Riunione Scientifica dell'Istituto Italiano di Preistoria e Protostoria; pp. 31-37. I.I.P.P., Firenze.

Biddittu, I., Canetri, E., Comerci, V., Germani, M., Picchi, G., 2012. Nuove ricerche nel giacimento del Paleolitico inferiore di Lademagne, S. Giovanni Incarico (Frosinone). In: Ghini, G., Mari, Z., (Eds.), Lazio e Sabina. Edizioni Quasar 9, 437-443.

Biddittu, I., Segre, A.G., 1977. Giacimenti preistorici e quaternario della provincial di Frosinone. Bollettino Istituto di Storia e Arte del Lazio Merionale 9, 1-2.

Biddittu, I., Segre, A.G., 1980. Utilizzazione dell'osso del Paleolitico inferiore italiano. In: Atti della XXIII Riunione Scientifica dell'Istituto Italiano di Preistoria e Protostoria; pp. 89-105. I.I.P.P., Firenze.

Boari, E., Tommasini, S., Maurenzi, M.A., Conticielli, S., 2009. Transition from ultrapotassic Kamafugitic to Subalkaline Magmas: $\mathrm{Sr}, \mathrm{Nd}$, and $\mathrm{Pb}$ isotope, trace element and ${ }^{40} \mathrm{Ar}-{ }^{39} \mathrm{Ar}$ age data from the Middle Latin Valley volcanic field, Roman Magmatic Province, central Italy. Journal of Petrology 50, 13271357.

Boschian, G., Saccà, D., 2015. In the elephant, everything is good: carcass use and re-use at Castel di Guido (Italy). Quaternary International 361, 288-296.

Brenet, M., Bourguignon, L., Colonges, D., Folgado, M., Jarry, M., Lelouvier, L.-A., Mourre, V., Turq, A., 2014. Les technocomplexes au début du Paléolithique moyen en Aquitaine septentrionale. In: Jaubert, J., Fourment, N., Depaepe, P. (Eds.), Transitions, Ruptures et Continuité En Préhistoire; pp. 81-101. Société Préhistorique Française, Paris.

Bridge, J.S., 2003. Rivers and Floodplains: Forms, Processes, and Sedimentary Record. Blackwells, Oxford.

Bridge, J.S., 2006. Fluvial facies models. In: Posamentier, H.W., Walker, R.G. (Eds.), Facies Models Revisited; pp. 85-170. Society for Sedimentary Geology, Tulsa.

Carbonell, E., Bermúdez de Castro, J.M., Parés, J.M., Pérez-González, A., Cuenca-Bescós, G., Ollé, A., Mosquera, M., et al., 2008. The first hominin of Europe. Nature 452, 465-469.

Carrara, C., Frezzotti, M., Giraudi, C., 1995. Stratigrafia plioquaternaria. In: Carrara, C. (Ed.), Lazio Meridionale, Sintesi delle ricerche geologiche multidisciplinari; pp. 62-85. E.N.E.A. Dipartimento Ambiente (Serie Studi e Ricerche), Roma.

Centamore, E., Di Manna, P., Rossi, D., 2007. Kinematic evolution of the Volsci Range: a new overview. Bollettino della Società Geologica Italiana 126, 159-172.

Centamore, E., Dramis, F., 2010. Note illustrative della Carta geologica d'Italia alla scala 1:50.000, Foglio 402 Ceccano. Regione Lazio, Roma.

Chiesa, S., Floris, B., Gillot, P.Y., Prosperi, L., Vezzoli, L., 1995. Il vulcano di Roccamonfina. In: Carrara, C. (Ed.), Lazio meridionale, sintesi delle ricerche geologiche multidisciplinari; pp. 128-149. E.N.E.A. Dipartimento Ambiente (Serie Studi e Ricerche), Roma.

Civetta, L., Innocenti, F., Lirer, L., Manetti, P., Munno, R., Peccerillo, A., Poli, G., Serri, G., 1979. Serie potassica ed alta in potassio dei Monti Ernici (Lazio Meridionale): considerazioni petrologiche e geochimiche. Rendiconti Società Italiana di Mineralogia e Petrologia 35, 27-249.

Civetta, L., Innocenti, F., Manetti, P., Peccerillo, A., Poli, G., 1981. Geochemical characteristics of potassic volcanics from Mts. Ernici (southern Latium, Italy). Contributions to Mineralogy and Petrology 78, 37-47.

Collinson, J., Mountney, N., Thompson, D., 2006. Sedimentary Structures. Terra - Dunedin Academic Press, Edimburgh.

Crochet, J.-Y.,Welcomme, J.-L., Ivorra, J., Ruffet, G., Boulbes, N., Capdevila, R., Claude, J., et al., 2009. Une nouvelle faune de vertébrés continentaux, associée à des artifacts dans le Pléistocène inférieur de l'Hérault (Sud de la France), ver 1,57 Ma. Comptes Rendus Palevol 8, 725-736.

Despriée, J., Moncel, M-H., Arzarello, M., Courcimault, G., Voinchet, P., Bahain, J.-J., Falguères, C., 2018. The 1 Myrs quartz assemblage from Pont-de-Lavaud (Centre, France). Journal of Quaternary Science 33, 639-661.

Devoto, G.,1965. Lacustrine Pleistocene in the lower Liri Valley (southern Latium). Geologica Romana 4, 291-368.

Di Vincenzo, F., Profico, A., Bernardini, F., Cerroni, V., Dreossi, D., Schlager, S., Zaio, P., et al., 2017. Digital reconstruction of the Ceprano calvarium (Italy), and implications for its interpretation. Scientific Reports 7, 13974 (DOI:10.1038/s41598-017-14437-2).

Falguères, C., Shao, Q., Han, F., Bahain, J.J., Richard, M., Perrenoud, C., Moigne, A.M., 2015. New ESR and U-series dating at Caune de l'Arago, France: a key-site for European Middle Pleistocene. Quaternary Geochronoogy 30, 547-553.

Fontana, F., Moncel, M.-H., Nenzioni, G., Onorevoli, G., Peretto, C., Combier, J., 2013. Widespread diffusion of technical innovations around 300,000 years ago in Europe as a reflection of anthropological and social transformations? New comparative data from the western Mediterranean sites of Orgnac (France) and Cave dall'Olio (Italy). Journal of Anthropological Archaeology 32, 478-498.

Food and Agriculture Organization (FAO), 2006. Guidelines for Soil Description. Food and Agriculture Organization of the United States, Rome.

Fornaseri, M., 1985. Geochronology of volcanic rocks from Latium, Italy. Rendiconti della Società Italiana di Mineralogia e Petrologia 40, 4-106.

Frezzotti, M.L., De Astis, G., Dallai, L., Ghezzo, C., 2007. Coexisting calc-alkaline and ultrapotassic magmatism at Monti Ernici, Mid Latina Valley (Latium, central Italy). European Journal of Mineralogy 19, 479-497.

Galadini, F., Messina, P., 2004. Early-Middle Pleistocene eastward migration of the Abruzzi Apennine (central Italy) extensional domain. Journal of Geodynamics 37, 57-81.

García-Medrano, P., Ollé, A., Mosquera, M., Cáceres, I., Carbonell, E., 2015. The nature of technological changes: the Middle Pleistocene stone tool assemblages from Galería and Gran Dolina-subunit TD10.1 (Atapuerca, Spain). Quaternary International 368, 92-111.

Geneste, J.M., 1991. Systèmes techniques de production lithique: variations technoéconomiques dans les processus de réalisation des outillages paléolithiques. Technology and Culture 17, 1-35.

Goren-Inbar, N., Sharon, G., 2006. Axe Age: Acheulian Toolmaking from Quarry to Discard. Equinox Publishing, London.

Grove, M., 2016. Population density, mobility, and cultural transmission. Journal of Archaeological Science 74, 75-84.

Head, M.J., Gibbard, P.L., 2015. Early-Middle Pleistocene transitions: linking terrestrial and marine realms. Quaternary International 389, 7-46. 
Herzlinger, G., Wynn, T., Goren-Inbar, N., 2017. Expert cognition in the production sequence of Acheulian cleavers at Gesher Benot Ya'aqov, Israel: a lithic and cognitive analysis. PloS one, 12, e0188337.

Hublin, J.J., 2009. The origin of Neandertals. Proceedings of the National Academy of Sciences of the United States of America 106, 16022-16027.

Key, A. J., Proffitt, T., Stefani, E., Lycett, S.J., 2016. Looking at handaxes from another angle: Assessing the ergonomic and functional importance of edge form in Acheulean bifaces. Journal of Anthropological Archaeology 44, 43-55.

Kleinen, T., Hildebrandt, S., Prange, M., Rachmayani, R., Müller, S., Bezrukova, E., Brovkin, V., Tarasov, P.E., 2014. The climate and vegetation of Marine Isotope Stage 11-model results and proxy-based reconstructions at global and regional scale. Quaternary International 348, 247-265.

Lamotte, A., Tuffreau, A., 2016. Acheulean of the Somme basin (France): assessment of lithic changes during MIS 12 to 9. Quaternary International 409, 54-72.

Lang, N., Wolff, E.W., 2011. Interglacial and glacial variability from the last $800 \mathrm{ka}$ in marine, ice and terrestrial archives. Climate of the Past 7, 361-380.

Lefèvre, D., Raynal, J.P., Vernet, G., Kieffer, G., Piperno, M., 2010. Tephro-stratigraphy and the age of ancient Southern Italian Acheulean settlements: the sites of Loreto and Notarchirico (Venosa, Basilicata, Italy). Quaternary International 223, 360-368.

Limondin-Lozouet, N., Antoine, P., Bahain, J.-J., Cliquet, D., Coutard, S., Dabkowski, J., Ghaleb, B., Locht, J.-L., Nicoud, E., Voinchet, P., 2015. North-West European MIS 11 malacological successions: a framework for the timing of Acheulean settlements. Journal of Quaternary Science 30, 702-712.

Maasch, K.A., 1988. Statistical detection of the mid-Pleistocene transition. Climate Dynamics 2, 133-143.

Manzi, G., 2012. On the trail of the genus Homo between archaic and derived morphologies. Journal of Anthropological Sciences 90, 99-116.

Manzi, G., 2016. Humans of the Middle Pleistocene: the controversial calvarium from Ceprano (Italy) and its significance for the origin and variability of Homo heidelbergensis. Quaternary International 411, 254-261.

Manzi, G., Magri, D., Milli, S., Palombo, M.R., Margari, V., Celiberti, V., Barbieri, et al., 2010. The new chronology of the Ceprano calvarium (Italy). Journal of Human Evolution 59, 580-585.

Manzi, G., Magri, D., Palombo, M.R., 2011. Early-Middle Pleistocene environmental changes and human evolution in the Italian peninsula. Quaternary Science Reviews 30, 1420-1438.

Manzi, G., Mallegni, F., Ascenzi, A., 2001. A cranium for the earliest Europeans: phylogenetic position of the hominid from Ceprano, Italy. Proceedings of the National Academy of Sciences of the United States of America 98, 10011-10016.

Margari, V., Roucoux, K., Magri, D., Manzi, G., Tzedakis, P.C., 2018. The MIS 13 interglacial at Ceprano, Italy, in the context of Middle Pleistocene vegetation changes in southern Europe. Quaternary Science Reviews 199, 144-158.

Maslin, M.A., Ridgwell, A.J., 2005. Mid-Pleistocene revolution and the 'eccentricity myth.' In: Head, M.J., Gibbard, P.L. (Eds.), Early-Middle Pleistocene Transition: The Land-Ocean Evidence. Special Publication 247. Geological Society of London, London, pp. 19-34.

Masson-Delmotte, V., Stenni, B., Pol, K., Braconnot, P., Cattani, O., Falourd, S., Kageyama, M., et al., 2010. EPICA Dome C record of glacial and interglacial intensities. Quaternary Science Reviews 29, 113-128.

McClymont, E.L., Sosdian, S.M., Rosell-Melé, A., Rosenthal, Y., 2013. Pleistocene sea surface temperature evolution: early cooling, delayed glacial intensification, and implications for the mid-Pleistocene climate transition. Earth-Science Reviews 123, 173-193.

McNabb, J., 2005. Hominins and the Early-Middle Pleistocene transition: evolution, culture and climate in Africa and Europe. In: Head, M.J., Gibbard, P.L. (Eds.), Early-Middle Pleistocene Transitions: The Land-Ocean Evidence. Geological Society of London, London, pp. 287-304.

Moigne, A.M., Valensi, P., Auguste, P., García-Solano, J., Tuffreau, A., Lamotte, A., Barroso, C., Moncel, M.H., 2016. Bone retouchers from Lower Palaeolithic sites: Terra Amata, Orgnac 3, Cagny-l'Epinette and Cueva del Angel. Quaternary International 409, 195-212.

Moncel, M.-H., Schreve, D., 2016. European Acheuleans. The Acheulean in Europe: origins, evolution and dispersal. Quaternary International 411, 1-8.

Moncel, M.-H., Moigne, A.-M., Combier, J., 2012. Towards the Middle Palaeolithic in western Europe: the case of Orgnac 3 (southeastern France). Journal of Human Evolution 63, 653-666.

Moncel, M.-H., Despriée, J., Voinchet, P., Tissoux, H., Moreno, D., Bahain, J.-J., Courcimault, G., Falguères, C., 2013. Early evidence of Acheulean settlement in northwestern Europe-La Noira Site, a 700,000 year-old occupation in the center of France. PLoS ONE 8, e75529 (DOI: 10.1371/journal.pone.0075529).

Moncel, M.-H., Ashton, N., Lamotte, A., Tuffreau, A., Cliquet, D., Despriée, J., 2015. The Early Acheulian of north-western Europe. Journal of Anthropological Archaeology 40, 302-331.

Moncel, M.-H., Arzarello, M., Peretto, C., 2016. Editorial: the Holstainian Eldorado. Quaternary International 409, 1-8.

Mounier, A., Marchal, F., Condemi, S., 2009. Is Homo heidelbergensis a distinct species? New insight on the Mauer mandible. Journal of Human Evolution 56, 219-246.

Mounier, A., Condemi, S., Manzi, G., 2011. The stem species of our species: a place for the archaic human cranium from Ceprano, Italy. PloS ONE 6, 1-11.

Muttoni, G., Scardia, G., Kent, D.V., Swisher, C.C., Manzi, G., 2009. Pleistocene magnetochronology of early hominin sites at Ceprano and Fontana Ranuccio, Italy. Earth and Planetary Science Letters 286, 255-268.

Narcisi, B., 1995. Elementi di tefrostratigrafia nella Valle Latina. In: Carrara, C. (Ed.), Lazio meridionale, sintesi delle ricerche geologiche multidisciplinari; pp. 126-128. E.N.E.A. Dipartimento Ambiente (Serie Studi e Ricerche), Roma.

Nicoud, E., 2013. What does the Acheulean consist of? The example of Western Europe (MIS 16-9). Mitteilungen der Gesellschaft für Urgeschichte 22, 41-60.

Nomade, S., Muttoni, G., Guillou, H., Robin, E., Scardia, G., 2011. First ${ }^{40} \mathrm{Ar} /{ }^{39} \mathrm{Ar}$ age of the Ceprano man (central Italy). Quaternary Geochronolology 6, 453-457.

O’Regan, H.J., Bishop, L.C., Lamb, A., Elton, S., Turner, A., 2005. Large mammal turnover in Africa and the Levant between 1.0 and 0.5 Ma. In: Head, M.J., Gibbard, P.L. (Eds.), Early-Middle Pleistocene Transitions: The Land-Ocean Evidence. Special Publication 247. Geological Society of London, London, pp. 231-249.

Palombo, M.R., 2014. Deconstructing mammal dispersals and faunal dynamics in SW Europe during the Quaternary. Quaternary Science Reviews 96, 50-71. 
Pereira, A., Nomade, S., Moncel, M.-H., Voinchet, P., Bahain, J.-J., Biddittu, I., Falguères, C., et al., 2018. Integrated geochronology of evidences of Acheulian sites from the southern Latium (central Italy): insights on human-environment interaction and the technological innovations during the MIS 11-MIS 10 period. Quaternary Sciences Reviews 187, 112-129.

Pereira, A., Nomade, S., Voinchet, P., Bahain, J. J., Falguères, C., Garon, H., Lefèvre, D., Raynal, J.-P., Scao, V., Piperno, M., 2015. The earliest securely dated hominin fossil in Italy and evidence of Acheulian occupation during glacial MIS 16 at Notarchirico (Venosa, Basilicata, Italy). Journal of Quaternary Science 30, 639-650.

Peretto, C., Arzarello, M., Bahain, J.-J., Boulbes, N., Dolo, J.-M., Douville, E., Falguères, C., et al., 2016. The Middle Pleistocene site of Guado San Nicola (Monteroduni, central Italy) on the Lower/Middle Palaeolithic transition. Quaternary International 411, 301-315.

Piperno, M. (Ed.), 1999. Notarchirico. Un sito del Pleistocene Medio iniziale nel bacino di Venosa. Osanna Edizioni, Venosa.

Piperno, M., Biddittu, I., 1978. Studio tipologico ed interpretazione dell'industria acheuleana e premusteriana dei livelli m e d di Torre in Pietra (Rome). Quaternaria 20, 441-535.

Poirier, R.K., Billups, K., 2014. The intensification of northern component deepwater formation during the mid-Pleistocene climate transition. Paleoceanography 29, 1046-1061.

Premo, L.S., Hublin, J.-J., 2009. Culture, population structure, and low genetic diversity in Pleistocene hominins. Proceedings of the National Academy of Sciences 106, 33-37.

Radmilli, A.M., Boschian, G., 1996. Gli scavi a Castel di Guido. Il più antico giacimento di cacciatori del Paleolitico inferiore nell'Agro Romano. Istituto Italiano di Preistoria e Protostoria, Firenze.

Rightmire, G.P., 1998. Human evolution in the Middle Pleistocene: the role of Homo heidelbergensis. Evolutionary Anthropology 6, 218-227.

Rightmire, G.P., 2008. Homo in the Middle Pleistocene: hypodigms, variation, and species recognition. Evolutionary Anthropology $17,8-21$.

Roebroeks, W., Villa, P., 2011. On the earliest evidence for habitual use of fire in Europe. Proceedings of the National Academy of Sciences of the United States of America 108, 5209-5214.
Ruddiman, W.F., Raymo, M., McIntyre, A., 1986. Matuyama 41,000-year cycles: North Atlantic Ocean and northern hemisphere ice sheets. Earth and Planetary Science Letters 80, 117-129.

Saltzman, B., Maasch, K.A., 1988. Carbon cycle instability as a cause of the late Pleistocene ice age oscillations: modeling the asymmetric response. Global Biogeochemical Cycles 2, 177-185.

Scott, B., Ashton, N., 2011. The Early Middle palaeolithic: the European Context. In: Ashton, N., Lewis, S.G., Stringer, C. (Eds.), The Ancient Human Occupation of Britain. Quaternary Science 14, 91-113.

Stringer, C.B., 2012. The status of Homo heidelbergensis (Schoetensack 1908). Evolutionary Anthropology 21, 101-107.

Texier, P.-J., Roche, H., 1995. The impact of predetermination on the development of some Acheulean chaînes opératoires. In: Bermúdez de Castro, J., Arsuaga, J.L., Carbonell, E. (Eds.), Evolucion humana en Europa y los yacimientos de la Sierra de Atapuerca. Junta de Castilla y Leon, Vallaloid, pp. 403-420.

Toro-Moyano, I., de Lumley, H., Fajardo, B., Barsky, D., Cauche, D., Celiberti, V., Grégoire, S., Martinez-Navarro, B., Espigares, M.P., Ros-Montoya, S., 2009. L'industrie lithique des gisements du Pléistocène inférieur de Barranco León et Fuente Nueva 3 à Orce, Grenade, Espagne. L'Anthropologie 113, 111-124.

Vallverdú, J., Saladié, P., Rosas, A., Huguet, R., Cáceres, I., Mosquera, M., Garcia-Tabernero, A., et al., 2014. Age and date for early arrival of the Acheulian in Europe (Barranc de la Boella, la Canonja, Spain). PLoS ONE 9, e103634 (DOI: 10.1371/journal.pone.0103634).

Villa, P., Soriano, S., Grün, R., Marra, F., Nomade, S., Pereira, A., Boschian, G., Pollarolo, L., Fang, F., Bahain, J.-J., 2016. The Acheulean and Early Middle Paleolithic in Latium (Italy): stability and Innovation. PLoS One 11, e0160516 (DOI: 10.1371/ journal.pone.0160516).

Voinchet, P., Moreno, D., Bahain, J.J., Tissoux, H., Tombret, O., Falguères, C., Moncel, M.-H., et al., 2015. New chronological data (ESR and ESR/U-series) for the earliest Acheulian sites of northwestern Europe. Journal of Quaternary Science 30, 610-622.

Wiśniewski, A., 2014. The beginnings and diversity of Levallois methods in the early Middle Palaeolithic of central Europe. Quaternary International 326-327, 364-380. 